\title{
Soil Organic Matter Quality From Soils Cropped by Traditional Peasants
}

\author{
Luciano Pasqualoto Canellas ${ }^{1}$, Riccardo Spaccini ${ }^{2}$, Natália de Oliveira Aguiar ${ }^{1}$, Maria Raquel Garcia Vega ${ }^{3}$ \& \\ Fábio Lopes Olivares ${ }^{1}$ \\ ${ }^{1}$ Universidade Estadual do Norte Fluminense Darcy Ribeiro (UENF), Núcleo de Desenvolvimento de Insumos \\ Biológicos para Agricultura Av. Alberto Lamego, 2000, CEP 28013-602 Campos dos Goytacazes, Rio de \\ Janeiro, Brazil \\ ${ }^{2}$ Centro Interdipartimentale sulla Risonanza Magnetica Nucleare CERMANU Università di Napoli Federico II, \\ via Università 100, 80055, Portici, Italy \\ 3 Laboratório de Ciências Químicas, UENF Av. Alberto Lamego, 2000, CEP 28013-602 Campos dos \\ Goytacazes, Rio de Janeiro, Brazil \\ Correspondence: Luciano Pasqualoto Canellas, Universidade Estadual do Norte Fluminense Darcy Ribeiro \\ (UENF), Núcleo de Desenvolvimento de Insumos Biológicos para Agricultura Av. Alberto Lamego, 2000, CEP \\ 28013-602 Campos dos Goytacazes, Rio de Janeiro, Brazil. Tel: 55-22-2739-7198. E-mail: canellas@uenf.br
}

Received: August 26, 2014 Accepted: October 5, 2014 Online Published: October 8, 2014

doi:10.5539/sar.v3n4p63 URL: http://dx.doi.org/10.5539/sar.v3n4p63

\begin{abstract}
In this work we have analyzed soil samples from Oxisols collected from two traditional communities, one formed by Guarany Indians at South of Brazil and other by African descendants on North of Rio de Janeiro State, Brazil. The content and fractional composition of humus was investigated and the isolated humic acids (HAs) were characterized by elemental composition, ${ }^{13} \mathrm{C}$ solid-state nuclear magnetic resonance, and high-performance size exclusion chromatography. The bioactivity of HAs was evaluated considering the effects on root growth of maize seedlings. Chemical properties from adjacent soils under native forest were used as control samples. The local field sites matching the traditional cropping requirements, were characterized by higher soil chemical fertility and soil organic matter hydrophobicity, as compared to the land plots considered as inadequate by rural peasants. The HAs from cropped soils revealed significant differences in respect to content, hydrophobicity, biostimulation and molecular dimension. Although all humic extracts promoted, both, root growth and the stimulation of lateral root emergence over control, the HAs from preferential local sites, revealed a larger bioactivity response on root stimulation even at lower concentration. The assessment of soil quality issued by local farmers, showed a valuable fitting with bio-chemical fertility indicators and SOM hydrophobicity.
\end{abstract}

Keywords: soil organic matter, humic acids, traditional knowledge, NMR, physiological effects

\section{Introduction}

\subsection{Introduce the Problem}

The soil organic matter (SOM) is a key driving factor for the long term sustainability of agro-ecosystems. Its effectiveness is closely related with the adoption of suitable soil management practices, providing a steady state equilibrium with respect to amount, composition and dynamics of different organic matter pools. However, the connection among bio-chemical characteristics, quality indicators and agronomic functions and properties of SOM, remain wrapped by light and shade effects. In particular, the existing gap between scientific approaches on SOM studies, with, either, the operative cropping experiences and the practical farmers appraisal of specific soil managements, is worthwhile to be investigated. With this respect, a useful standpoint may be represented by productive "marginal" areas of small, long term founded communities, in which original local techniques have been developed within a limited or weak combination with agro-technologies. In fact, traditional farmers have developed diverse worldwide locally adapted agricultural systems, that strongly contribute to, both, soil quality improvement and to long term maintenance of agro-ecosystem.

The role of organic matter for soil fertility has long been known. The relationship between dark soils, use of organic wastes and agricultural production were observed by traditional peasants for thousands years (Vaughan 
\& Malcolm, 1985). The acknowledged positive relationship between SOM and soil properties is consistent with research results and on-farm observation and experimentation (Herrick \& Wander, 1997). The increasing amount of SOM in surface soil layers may positively affect the soil quality functions, thus directly improving microbial activity, soil-plant interactions, energy and metabolic regulations, and the soil structural stability (Diacomo \& Montemurro, 2010). Humic substances (HS), currently defined as the end product of the decay processes of plant, animals and microbial cells, represent the main constituent of SOM, the high fertility soils -being relatively enriched with humic acids (HA) (Kononova, 1961; Orlov, 1985, Stevenson, 1994).

Soil HS can be considered as a very complex mixture of faunal, microbial and plant biopolymers and their degradation products (Kelleher \& Simpson, 2006). Proteins, lignin, carbohydrates and aliphatic biopolymers are the major precursors of humic components, present at various stages of decomposition and held together by weak interactions and hydrophobic associations in supramolecular arrangements of different molecular sizes (Piccolo, 2001). Although the investigation on the relationship between chemical properties of HS with soil quality and management practices is not a simple task, there is an increasing scientific evidence on the correlation of molecular characteristics of HA and plant root stimulation (Canellas et al., 2012; Aguiar et al., 2013). Nardi et al. (2004) found that HA extracted from the upper layer of soil under continuous long-term organic matter addition, exhibited larger hormonal-like activity than the humic extracts from deeper layer. This finding is in line with recent understanding that biological activity in the surface soil layer releases bioactive molecules and/or hormones, which can be preserved into HS complex hydrophobic structures.

Farmer know how and cropping experience, can offer many insights about sustainable management of agroecosystems and use of local indicators of soil quality based on crop yield and plant vigor (Altieri, 2002; Barrios et al., 2006; Lefèvre et al., 2013). However, results linking local indicators of soil quality and chemical properties of HAs are scarce despite their acknowledged central role on soil functions.

In this work we collaborated with to two traditional communities, one formed by Guarany Indians at South of Brazil and other by African descendents at North of Rio de Janeiro State, with the aim to observe a possible relationship between the local viable selection of best fields for subsistence crop production, with the molecular characteristics of HAs, the soil chemical fertility and plant root stimulation.

\section{Method}

\subsection{Site Description and Soil Samples Collection}

\subsubsection{Guarany Indigenous Community}

The indigenous reserve area known as Salto Grande do Jacuí comprises 234 ha with 35 families (around 187 people). The reserve is located at $6 \mathrm{~km}$ from a town in Salto do Jacuí city, at the margins of the Jacuí river, in the State of Rio Grande do Sul, Brazil. The reserve presents 151 ha of native forest, 73 ha of eucalyptus reforestation and 10 ha under crops. The crop system is traditional slash and burn tillage and multiple cropping systems. The Guarany peasants used their own seeds to crop maize (Zea mays), cassava (Manihot esculenta Crantz), peanuts (Arachis hypogea L.), pumpkin (Cucubita pepo), tobacco (Nicotiana tabacum), watermelon (Citrullus lanatus), beans (Phaseolus vulgaris). All these plants are cropped together with sowing time difference. The Oxisol (Perox) (Soil Survey Staff, 2010) is the main soil order in the reserve. The Guarany families depend on Federal Government Assistance Programme (social fellow) to survive, although they get some off-farm income especially as artisans.

\subsubsection{Brazilian-African Descents Community - Quilombolas}

This community is formed by a family nucleus constituted by two brothers of 94 and 96 years of age and their descendents, counting about 125 persons. Their living area comprises around 20 ha located at $21^{\circ} 21^{\prime} 21.50^{\prime \prime} \mathrm{S}$ e $41^{\circ} 00^{\prime} 02.21^{\prime \prime}$ in São Francisco do Itabapoana, North of Rio de Janeiro State, Brazil, a transient region between the coastline and tertiary sediments. Soils are predominately Oxisols (Soil Survey Staff, 2010) with very low natural fertility. Cropping is characterized by subsistence agriculture without external input using only manual work and multiple cropping system (cassava, beans, peatnuts, pumpkin, okra, pineapple).

\subsection{Eliciting Information From Farmers}

The work started with the simple idea to fit the local soil quality indicators and the chemical nature of soil organic matter (Barrios et al., 2006). In the Guarany community, we used previous long-time experience of rural extension work to contact community members. After this, we conducted a pre-organized interview in native language (Guarany) with old members (more than $80 \mathrm{yr}$ ), including several questions on environmental perception, such as awareness of soil erosion, soil taxonomy, perceived suitability of selected climatic-edaphic factors for agricultural productivity and site suitability evaluation. The interview objective was only to permit a 
subsequent comparison with soil chemical analysis. Soil samples were collected at sites and depths indicated by the Guarany Indians, using a participatory wealth ranking method. At the Quilombolas, a couple of investigators (male and female) lived during three summer months with the community. In this time, the investigators participated to routine work and interviewed old peoples. Soil samples also were collected from local sites indicated by peasants at $0-0.20 \mathrm{~m}$ of depth using composite samples formed by 10 sub-samples at each local appointed by peasants. In both instances (Guarany and Quilombolas), samples from topsoil (0-0.20 m) of native forest were collected as reference. All soil samples were air-dried, passed through a 2-mm sieve, and analyzed in the Soil Laboratory of Universidade Estadual do Norte Fluminense. Soil pH was determined in a 1:2.5 soil water ratio, texture was measured by applying the hydrometer method, and soil organic carbon was determined by the wet oxidation method. Available $\mathrm{P}$ was determined with the Bray method, while total $\mathrm{N}$ was determined by Kjedahl digestion, distillation and titration. Exchangeable $\mathrm{K}$ was analyzed using atomic absortion spectrophotometry following ammonium acetate extraction. Cation Exchange Capacity (CEC) was determined at pH 7 using ammonium acetate as exchanger cation. Table 1 shown the main characteristics used to soil description by peasant ears in this work.

\subsection{Quantification of Humic Substances and Total Carbon}

The quantification of the three operationally defined humic substances (HS) fractions, fulvic acids (FA), humic acids (HA) and humin (H) was done by the method described by Stevenson (1994). The method is based on the extraction and separation of the alkali soluble (HA and FA) from the insoluble fractions (H) by aqueous solution of $0.5 \mathrm{M} \mathrm{NaOH}$, and separation of HA from FA using aqueous solution of $6 \mathrm{M} \mathrm{HCl}$. The determination of $\mathrm{C}$ in the $\mathrm{H}$ fraction was based on digestion by $0.167 \mathrm{M} \mathrm{K}_{2} \mathrm{Cr}_{2} \mathrm{O}_{7}$ using tubes placed in heating blocks, and subsequent titration by $0.25 \mathrm{M} \mathrm{Fe}\left(\mathrm{NH}_{4}\right)_{2}\left(\mathrm{SO}_{4}\right)_{2} \cdot 6 \mathrm{H}_{2} \mathrm{O}$. The $\mathrm{C}$ in the $\mathrm{HA}$ and FA fractions was determined similarly, but using $0.042 \mathrm{M} \mathrm{K}_{2} \mathrm{Cr}_{2} \mathrm{O}_{7}$ and $0.0125 \mathrm{M} \mathrm{Fe}\left(\mathrm{NH}_{4}\right)_{2}\left(\mathrm{SO}_{4}\right)_{2} \cdot 6 \mathrm{H}_{2} \mathrm{O}$. The ratios of HA by FA (HA:FA) was calculated to characterize the hydrophobic degree of soluble humified fraction of SOM (Piccolo, 2002). Total C in the soil samples and humic fractions was measured by combustion at $925^{\circ} \mathrm{C}$ using a Perkin Elmer CHN/O Analyzer 2400 Series II (Perkin Elmer Life and Analytical Sciences, Inc. Boston, MA, EUA).

\subsection{Extraction and Analyses of $H A$}

Humic substances were extracted and purified as reported elsewhere (Canellas et al., 2008a). Briefly, $200 \mathrm{~g}$ of 2 $\mathrm{mm}$ sieved soil sample was shaken overnight in $1000 \mathrm{~mL}$ of a $0.5 \mathrm{M} \mathrm{NaOH}$ solution under $\mathrm{N}_{2}$ atmosphere. Humic acids were precipitated from the extracting solution by adding $6 \mathrm{M} \mathrm{HCl}$ until $\mathrm{pH} 1$. Ash was removed first by three cycles of dissolution in $0.5 \mathrm{M} \mathrm{NaOH}$ followed by flocculation in $6 \mathrm{M} \mathrm{HCl}$, followed by shaking $\mathrm{HA}$ twice in a $0.25 \mathrm{M}$ hydrofluoric acid/ $\mathrm{HCl}$ solution for $24 \mathrm{~h}$. Humic acids were redissolved in $0.5 \mathrm{M} \mathrm{NaOH}$ and passed through a strong cation-exchange resin (Dowex 50) to eliminate the remaining divalent and trivalent metals. The eluate was precipitated at $\mathrm{pH} 1$, dialyzed (cutoff $1000 \mathrm{Da}$ ) against deionized water until $\mathrm{Cl}^{-}$free, and then it was freeze dried. After homogenization, $300 \mathrm{mg}$ of $\mathrm{HA}$ was suspended in $\mathrm{H}_{2} \mathrm{O}$, titrated to $\mathrm{pH} 7$, and freeze dried again. The HA elemental composition was evaluated using a CHN Perkin Elmer autoanalyzer (14800). The oxygen content was obtained by difference and the ash content by incineration of $50 \mathrm{mg} \mathrm{HA}$ at $700^{\circ} \mathrm{C}$ for $8 \mathrm{~h}$. The resulting ash content was less than $3 \%$ in all samples.

\subsection{Solid-State Nuclear Magnetic Resonance Spectroscopy}

Cross-polarization magic angle spinning (CPMAS) 13C nuclear magnetic resonance (13C-NMR) spectra were acquired with a Bruker AVANCEi 300, equipped with a 4-mm wide bore MAS probe, operating at a 13C resonating frequency of $75.475 \mathrm{MHz}$. Samples (100-200 mg) were packed in 4-mm zirconia rotors with Kel-F caps and were spun at $13 \mathrm{~T} 1 \mathrm{kHz}$. A $1 \mathrm{H}$ ramp sequence was used with a contact time of 1 millisecond to account for possible inhomogeneity of the Hartmann-Hahn condition. Two thousand scans with 3782 data points were collected by using an acquisition time of 25 milliseconds, and a recycle delay of $2.0 \mathrm{sec}$. The Bruker Topspin 1.3 software was used to collect and elaborate the spectra. All free induction decays were transformed by applying a 4-k zero filling and a line broadening of $75 \mathrm{~Hz}$. Spectra were integrated in the chemical shift (ppm) resonance intervals of 230-190 (carbonyls of ketones, quinones, aldehydes, and carboxyls), 162-110 (aromatic and olefinic sp2 carbons), 110-90 (anomeric carbons in carbohydrate-like structures), 90-65 (C-O systems, such as alcohols and ethers), $65-46\left(\mathrm{OCH}_{3}, \mathrm{C}-\mathrm{N}\right.$ groups, and complex aliphatic carbons), and $46-0 \mathrm{ppm}$ (mainly $\mathrm{CH}_{2}$ and $\mathrm{CH}_{3} \mathrm{sp}^{3}$ carbons). The relative areas of alkyl (46-0 ppm) and $\mathrm{sp}^{2}(162-110 \mathrm{ppm})$ carbon components were summed to represent the proportion of hydrophobic carbons in humic samples (degree of hydrophobicity [HB]). Similarly, the summation of relative areas in intervals related to polar groups (185-162, 90-65, and 65-46 ppm) indicated the degree of carbon hydrophilicity (HI). Both $\mathrm{HB}$ and $\mathrm{HI}$ values were used to calculate the $\mathrm{HB} / \mathrm{HI}$ ratio. 


\subsection{High-Performance Size Exclusion Chromatography From HA}

The high-performance size exclusion chromatography (HPSEC) system consisted of a Shimadzu LC-10ADVP solvent pump and two detectors in a series, a UV-Vis variable wavelength detector (Perkin-Elmer LC-295) set at $280 \mathrm{~nm}$, and a Refractive Index (RI) detector (Fisons Instruments, Refractomonitor IV). A rheodyne rotary injector, equipped with a 100-KL sample loop, was used to load the calibration standards and humic solutions. Size exclusion separation occurred through a Polysep-GFC-P $3000(600 \mathrm{~mm}$ per $7.8 \mathrm{~mm}$ i.d.) column (Phenomenex), preceded by a Polysep-GFC-Guard column $(35 \mathrm{~mm}$ per $7.8 \mathrm{~mm}$ i.d.) and by a $0.2-\mathrm{KL}$ stainless steel inlet filter. Both columns were packed with rigid spherical silica gels chemically bonded with hydrophilic compounds. Phosphate buffer $\left(\mathrm{NaH}_{2} \mathrm{PO}_{4}, 0.0625 \mathrm{M}, \mathrm{pH} 7\right.$, ionic strength $\left.0.104 \mathrm{M}\right)$ was used to dissolve $\mathrm{HA}(0.6$ $\mathrm{g} \mathrm{L}-1)$ and as chromatographic eluent at $0.6 \mathrm{~mL}$ min-1 flow rate. The void volume $(\mathrm{V} 0=10.96 \mathrm{~mL})$ and the total permeation volume $(\mathrm{Vt}=25.88 \mathrm{~mL})$ of the column were determined with Blue dextran $(2000 \mathrm{Kd})$ and water $(18$ d), respectively. The HPSEC system was calibrated using sodium polystyrenesulfonate standards (Polymer Standard Service, AQ5 Mainz, Germany) with molecular weight ranging from 1100 to 130,000 d. Size exclusion chromatograms for both UV and RI detector were evaluated using Origin 6.1. Calculation of apparent weight-average molecular weight values (Mw) was carried out by the method of Striegel et al. (2009).

\subsection{Plant Growth and HA Treatment}

Maize (Zea mays var. UENF-506-8) seed was provided by Plant Science Laboratory of UENF, were surface sterilized by soaking in $0.5 \%(\mathrm{w} / \mathrm{v}) \mathrm{NaClO}$ for $30 \mathrm{~min}$, followed by rinsing and then soaking in water for $6 \mathrm{~h}$. Afterward, these seeds were sown on wet paper and germinated in the dark at $28{ }^{\circ} \mathrm{C}$. A preliminary assay was conducted by using 4-d-old maize seedlings with roots approximately $0.5 \mathrm{~cm}$ long. These were transferred into a solution containing $2 \mathrm{mM} \mathrm{CaCl}_{2}$ and HAs varying concentrations: $0,0.5,1.0,2.0,4.0,6.0$ and $8.0 \mathrm{mM} \mathrm{C} \mathrm{L}^{-1}$. A minimal medium $\left(2 \mathrm{mM} \mathrm{CaCl}_{2}\right)$ has been used to avoid any interference from nutrients tha tmay act synergistically with humic matter on plant growth and metabolism. The root growth was measured at 7 thd by using Delta-T scan software (Delta-TDevices, Cambridge, UK).

\section{Results}

Multicropping system used by the Quilombolas community is characterized by cassava, pumpkin, maize, beans, pineapple, okra, cultivated in the same site adopting a local complex system for timing and spacing of plant type separation. Due to sea proximity the altitude is the principal topographical factor to choose cultivation sites (Table 1), in order to avoid risk of floods and $\mathrm{Na}$ and $\mathrm{Cl}$ accumulation in soil (Table 1 and Table 2).

Table 1. Summary of site description by traditional peasants

\begin{tabular}{|c|c|c|c|}
\hline Sample & Vegetal cover & Evaluation & Soil indicators \\
\hline & & & Quilombolas sites \\
\hline Q1 & Native Forest & $\begin{array}{l}\text { Reference } \\
\text { sample }\end{array}$ & \multirow{3}{*}{$\begin{array}{l}\text { Dark soil is considered good for cultivation and denominated "fatty soil" } \\
\text { due organic matter incorporation. Presence of earthworm and arthropods. } \\
\text { The topographical position is determinant in choosing local sites for crop } \\
\text { production due limitation inherent to flood risk }\end{array}$} \\
\hline Q2 & $\begin{array}{l}\text { Multicrop } \\
\text { system: cassava, } \\
\text { beans, maize, } \\
\text { okra }\end{array}$ & $\begin{array}{l}\text { Good for } \\
\text { tillage }\end{array}$ & \\
\hline Q3 & $\begin{array}{l}\text { Spontaneous } \\
\text { vegetation after } \\
\text { deforestation }\end{array}$ & $\begin{array}{l}\text { Not } \\
\text { adequate } \\
\text { for tillage }\end{array}$ & \\
\hline \multicolumn{4}{|r|}{ Guarany sites } \\
\hline G1 & Native Forest & $\begin{array}{l}\text { Reference } \\
\text { samples }\end{array}$ & \multirow{5}{*}{$\begin{array}{l}\text { Topography was used to choose local sites for deforestation. Slash and } \\
\text { Burn is a typical tillage system and cultivation time is used, together with } \\
\text { crop production and vigor, as soil indicator. Dark soil is the main soil } \\
\text { quality indicator. }\end{array}$} \\
\hline $\mathrm{G} 2$ & $\begin{array}{l}\text { Eucaliptus } \\
\text { reforestation }\end{array}$ & $\begin{array}{l}\text { Reference } \\
\text { samples }\end{array}$ & \\
\hline G3 & $\begin{array}{l}\text { Multicrop } \\
\text { systems }\end{array}$ & $\begin{array}{l}\text { Very good } \\
\text { for tillage }\end{array}$ & \\
\hline G4 & beans & good & \\
\hline G5 & $\begin{array}{l}\text { Multicrop } \\
\text { systems }\end{array}$ & Tired soil & \\
\hline
\end{tabular}


Table 2. Soil chemical properties and humus composition

\begin{tabular}{|c|c|c|c|c|c|c|c|c|c|c|c|c|c|c|}
\hline samples & $\mathrm{pH}$ & $\mathrm{P}$ & $\mathrm{K}$ & $\mathrm{Ca}$ & $\mathrm{Mg}$ & $\mathrm{Al}$ & $\mathrm{H}+\mathrm{Al}$ & $\mathrm{Na}$ & CEC & TOC & CHum & CHA & CFA & $\mathrm{HA} / \mathrm{FA}$ \\
\hline & - & mg.kg ${ }^{-1}$ & \multicolumn{7}{|c|}{ 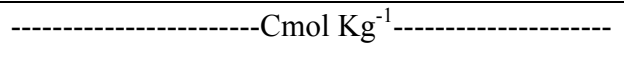 } & \multicolumn{4}{|c|}{ 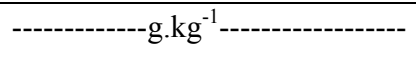 } & - \\
\hline & \multicolumn{14}{|c|}{ Quilombolas sites } \\
\hline Q1 & 4.6 & 6 & 0.19 & 0.9 & 2.2 & 2.6 & 22.3 & 0.22 & 6.1 & 34.51 & 15.6 & 2.79 & 8.79 & 0.32 \\
\hline Q2 & 6.2 & 4 & 0.01 & 2.6 & 0.3 & 0.0 & 3.1 & 0.16 & 3.1 & 8.62 & 1.00 & 0.10 & 0.21 & 0.48 \\
\hline Q3 & 8.5 & 11 & 0.03 & 4.9 & 0.4 & 0.0 & 0.0 & 0.69 & 5.6 & 9.53 & 1.50 & 0.70 & 5.23 & 0.13 \\
\hline \multicolumn{15}{|c|}{ Guarany Sites } \\
\hline G1 & 5.7 & 3 & 0.63 & 13.2 & 2.5 & 0.0 & 8.5 & 0.16 & 16.5 & 35.90 & 22.97 & 4.76 & 6.04 & 0.79 \\
\hline G2 & 5.8 & 24 & 0.58 & 8.7 & 2.3 & 0.0 & 9.9 & 0.18 & 11.6 & 31.40 & 10.91 & 4.46 & 6.86 & 0.65 \\
\hline G3 & 5.6 & 30 & 1.57 & 17.5 & 2.7 & 0.0 & 6.8 & 0.36 & 22.1 & 29.90 & 15.87 & 5.06 & 4.88 & 1.04 \\
\hline G4 & 5.6 & 11 & 1.35 & 9.6 & 1.6 & 0.0 & 7.1 & 0.24 & 12.8 & 21.10 & 10.33 & 3.63 & 5.86 & 0.62 \\
\hline G5 & 6.4 & 30 & 1.03 & 7.9 & 2.3 & 0.0 & 5.8 & 0.20 & 11.4 & 30.70 & 14.31 & 2.88 & 5.64 & 0.51 \\
\hline
\end{tabular}

TOC: total organic carbon; CHum, CHA and CFA: carbon content in Humin, Humic Acids and Fulvic Acids fractions, respectively.

The reference sample collected under forest topsoil showed high $\mathrm{Al}^{3+}$ content, however, since the SOM amount was relatively larger (Table 2), no restriction was observed for plant growth. The crops locally selected by peasants showed low content of toxic $\mathrm{Al}^{3+}$ and prevention of inundation.

Soils from Guarany reserve in South Brazil is very diverse from those found at Quilombola site, being mainly typical Oxisols with presence of hematite conferring an intense red color. Clay content is large $(380 \mathrm{~g} / \mathrm{kg})$ and chemical properties are favorable for multicropping, especially for the large CEC and available-P content (Table 2). As observed at the Quilombola site, relieve is important characteristic for the local selection of cropping sites, due to a rough landscape. However, mystic aspects are the most determinant trait to select areas for multi-cropping based in proper places to establish houses, which will be bounded (or surrounded) by plantations. Others values such as religious belief on the favourable influence of ancestor spirits, is also considered important decision point. In respect to forest topsoil samples, the site considered by ancient Guaranys as suitable cropping field (denominate as $y v y h u$ : dark earth) showed high fertility, as revealed by CEC, available-P, and low acidity (Table 2). Conversely the site considered as "tired" and not longer exploitable for tillage (G5, Table 1), revealed a lower content of exchangeable bases (Table 2).

As expected, total organic carbon (TOC) in both studied sites, were larger in forest topsoils than in tillage soil samples (Table 2), and a decrease of soil organic matter following multicropping system was observed. At Quilombola site, the TOC decrease was more evident, being around $75 \%$ for the yellow Oxisol $(85 \mathrm{~g}$ clay $/ \mathrm{kg}$ soil). For red Oxisols, TOC decrease was around $44 \%$ for the site considered as "tired", while the yvy-hu (which means good place for cultivation) showed a larger TOC maintenance, with a decrease of only $17 \%$ (Table 2). These differences cannot be attributed to variation in cultivation time, since all sites were cropped for eight years after forest cut.

The major humified fraction on forest topsoil was the residual fraction (humins), while fulvic acids (FA) were the major component of the alkaline extractable organic matter. In addition, an increase in HA was observed at the multicropping site (Table 2). The FA content was larger in the flood area probably due the high content of Na and elevated $\mathrm{pH}$. The distribution of humified organic fractions on Guarany sites were quite similar to Quilombolas, with humin as predominant humic fraction (Table 2). However, a noticeable increase in HA content was found in plot samples from $y v y-h u$ area, whereas lower HA content was observed in the area described as "tired" and inadequate to cultivation.

The data of elemental composition for Quilombolas soils (Table 3), revealed, in respect to forest top layer, an increasing $\mathrm{C}$ content in the HA from cropping fields. This finding is compatible with the decrease of O-rich carbohydrates shown by ${ }^{13} \mathrm{C}-\mathrm{CPMAS}-\mathrm{NMR}$ spectra of intact soils samples (Table 3). At Guarany sites, low C content was observed on $y v y-h u$ (HAG-3) soils, and, consequently, their HA showed larger O content. For this site, the largest $\mathrm{C}$ value was found for eucalyptus (HAG2) vegetation, followed by that in the "tired" site (HAG5). 
HPSEC efficiently discriminated among HA (Figure 1), providing a typical bimodal elution distribution in all samples. The ratio of the first exclusion peak (due to larger size components, Mwa) to the second peak (due to lower size components, Mwb) was used for HA comparison (Table 3).

Table 3. Chemical (elemental analysis), conformational (HPSEC) and spectroscopic ( $\left.{ }^{13} \mathrm{C}-\mathrm{CPMAS}-\mathrm{NMR}\right)$ properties of HA

\begin{tabular}{|c|c|c|c|c|c|c|c|c|c|c|c|}
\hline \multirow[t]{2}{*}{$\begin{array}{l}\text { Humic } \\
\text { acids }\end{array}$} & \multicolumn{4}{|c|}{ Elemental Analysis (\%) } & \multicolumn{2}{|l|}{$\begin{array}{l}\text { Peak } \\
\text { HPSEC }\end{array}$} & \multicolumn{4}{|c|}{ Carbon Distribution by NMR (\%) } & \multirow{2}{*}{$\begin{array}{l}\text { Hydrophobic } \\
\text { Index } \\
\qquad \mathrm{HB} / \mathrm{HI}^{3}\end{array}$} \\
\hline & $\mathrm{C}$ & $\mathrm{H}$ & $\mathrm{N}$ & $\mathrm{O}$ & $\mathrm{Mwa}^{1}$ & $\mathrm{Mwb}^{2}$ & $0-40$ & $40-110$ & $110-160$ & $160-200$ & \\
\hline \multicolumn{12}{|c|}{ Quilombolas samples } \\
\hline HAQ1 & 41.59 & 4.64 & 2.99 & 50.78 & 30 & 70 & 28.6 & 37.0 & 18.2 & 16.2 & 0.88 \\
\hline HAQ2 & 47.47 & 5.05 & 4.16 & 43.32 & 9 & 91 & 27.4 & 27.3 & 34.4 & 10.9 & 1.62 \\
\hline HAQ3 & 51.69 & 5.02 & 4.27 & 39.02 & 9 & 91 & 21.3 & 28.1 & 35.5 & 15.0 & 1.32 \\
\hline \multicolumn{12}{|c|}{ Guarany samples } \\
\hline HAG1 & 33.07 & 4.13 & 3.60 & 59.20 & 25 & 75 & 28.7 & 35.1 & 21.9 & 14.3 & 1.02 \\
\hline HAG2 & 51.15 & 5.16 & 4.85 & 38.83 & 20 & 80 & 21.6 & 39.4 & 23.0 & 16. & 0.81 \\
\hline HAG3 & 27.90 & 3.50 & 2.62 & 65.98 & 23 & 77 & 26.5 & 34.0 & 25.0 & 14.5 & 1.06 \\
\hline HAG4 & 46.31 & 4.70 & 4.70 & 44.28 & 12 & 88 & 17.7 & 35.3 & 31.0 & 16.0 & 0.95 \\
\hline HAG5 & 48.51 & 4.77 & 4.52 & 42.20 & 15 & 85 & 21.4 & 37.3 & 26.1 & 15.1 & 0.91 \\
\hline
\end{tabular}

1. Relative area under first HPSEC peak.

2. Relative area under second HPSEC peak.

3. Ratio of areas of hydrophobic NMR signals over those of hydrophilic NMR signals.

Apparently small humic size components increased with cultivation, in both Quilombola and Guarany sites. Forest topsoil (HAG1) showed 25\% of Mwa components and 75\% of Mwb. These values were changed to 15\% and $85 \%$, respectively in the tired area (HAG5), while the change was not large (23\% and $80 \%)$ in the $y v y-h u$ (HAG2). 

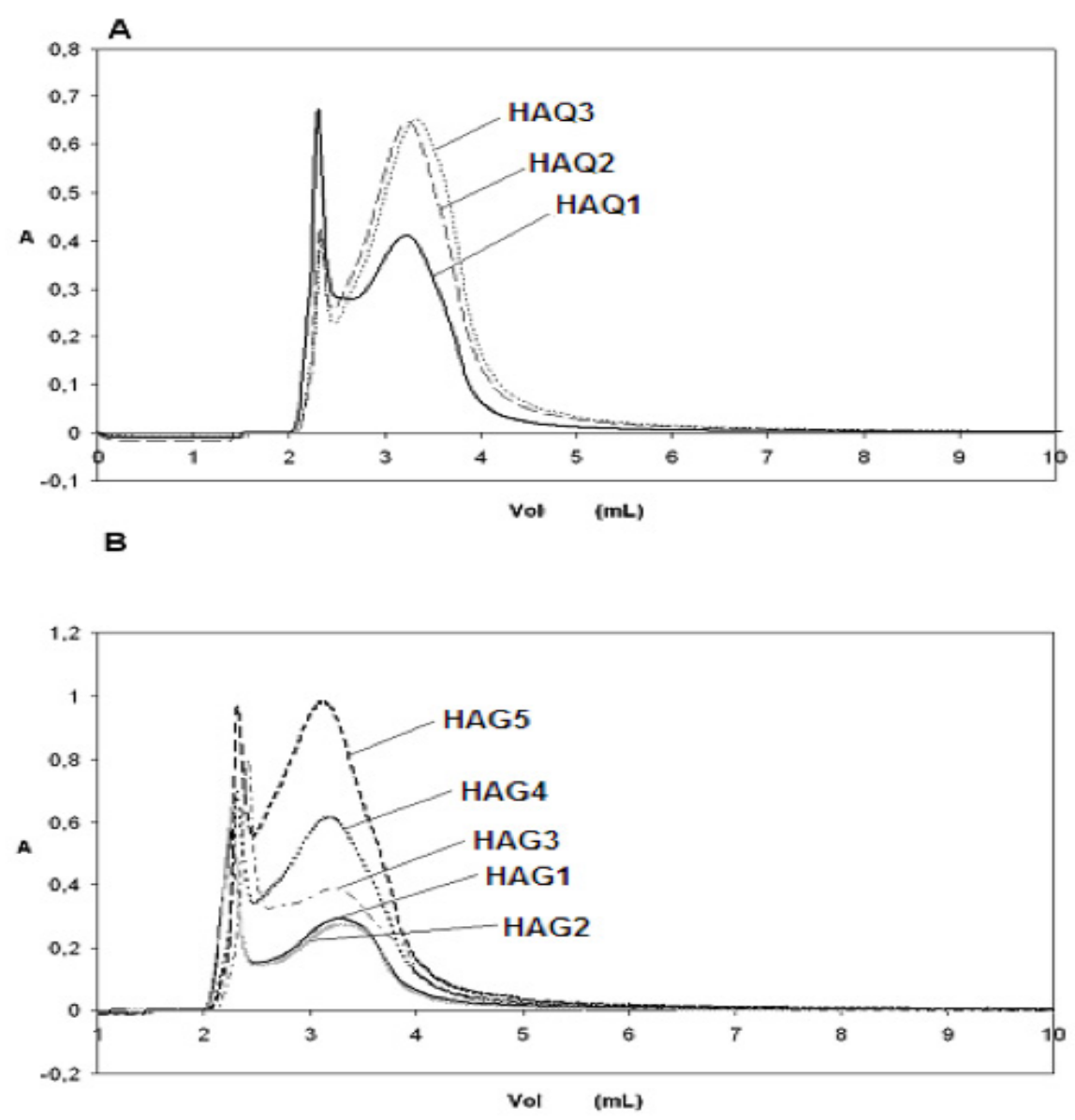

Figure 1. Size exclusion chromatograms of HA used in this study

Iron content on HA samples was negligible and made possible the $\mathrm{CP} / \mathrm{MAS}{ }^{13} \mathrm{C}$ NMR analyses of all HAs samples (Spectra not shown), whose integration area are shown in Table 3. The CPMAS 13C-NMR spectrum of HA from forest topsoil in Quilombola site, was characterized by a considerable amount of carboxylic carbon (200-160 ppm) and lower aromatic components (110- $160 \mathrm{ppm}$ ), while conversely that of HA isolated from multicropping soil, was rich in aromatic and poor in oxidized carboxylic-C. The HA extracted from Guarany samples showed less distinct difference in ${ }^{13} \mathrm{C}$ NMR spectra. However, HA collected from cultivated areas (HAG5 and HAG4) revealed a substantial decrease in alkyl-C as compared to forest topsoil (Table 3). In the other chemical shift regions the signals did not reveal evident differences among HA.

Related to plant growth promotion trait, all HA were able to increase the numbers of lateral root emergence in comparison with maize seedlings control (Figure 2A). The mean optimal concentration of HA in solution for secondary root stimulation was $2.71 \pm 0.34 \mathrm{mM} \mathrm{C/L}$ (Table 4). 

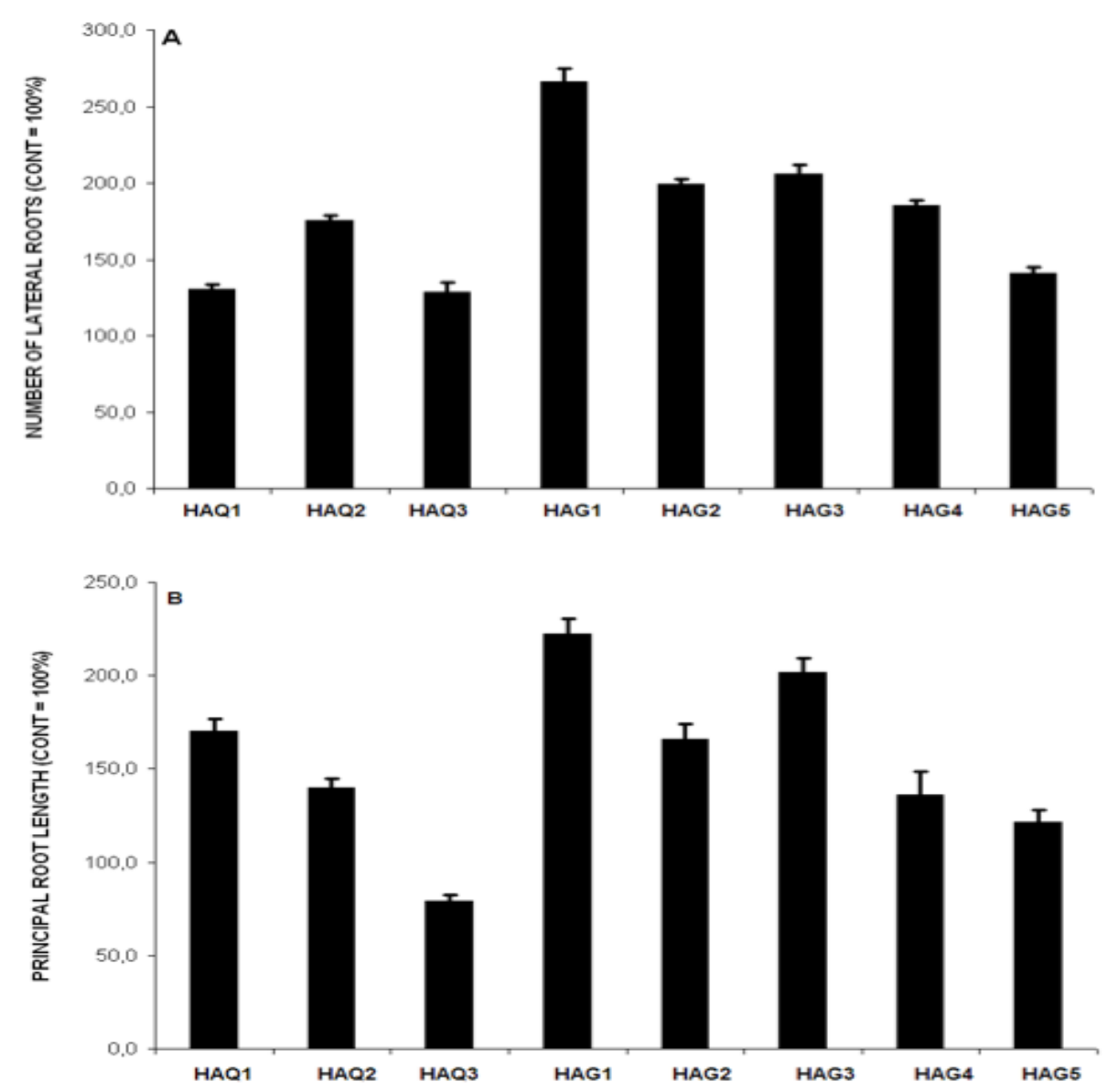

Figure 2. Number of lateral roots emerged (A) and length of principal axis (B) from maize seedlings treated with different HA. The values represent a mean followed by standard deviation

Table 4. Table 4 Regression equations, standard deviations, $\mathrm{P}$ and $\mathrm{R}^{2}$ values and optimal concentration for the stimulation of number of emerged lateral roots in Zea mays after treatment with different $\mathrm{C}$ concentrations in solutions of HA $(n=15)$

\begin{tabular}{cccccc}
\hline Samples $^{(1)}$ & $\begin{array}{c}\text { Regression equations } \\
\left(\mathrm{y}=\mathrm{b} 2 \mathrm{x}^{2}+\mathrm{b} 1 \mathrm{x}+\mathrm{b} 0\right)\end{array}$ & $\mathrm{R}^{2}$ & $\mathrm{SD}$ & $\mathrm{P}$ & $\begin{array}{c}\text { Optimal dose } \\
(\mathrm{dx} / \mathrm{dy}): \mathrm{b} 1+2\left(\mathrm{~b}^{2}\right) \mathrm{x}=0\end{array}$ \\
\hline HAQ1 & $\mathrm{y}=-2.8997 \mathrm{x}^{2}+16.970 \mathrm{x}+23.081$ & 0.85 & 1.82 & $<0.0001$ & 2.92 \\
HAQ2 & $\mathrm{y}=-2.3912 \mathrm{x}^{2}+14.124 \mathrm{x}+22.111$ & 0.72 & 2.67 & $<0.0004$ & 2.55 \\
HAQ3 & $\mathrm{y}=-2.4174 \mathrm{x}^{2}+14.821 \mathrm{x}+23.625$ & 0.8 & 2.03 & $<0.0001$ & 3.06 \\
HAG1 & $\mathrm{y}=-3.3916 \mathrm{x}^{2}+17.809 \mathrm{x}+32.041$ & 0.78 & 1.85 & $<0.0002$ & 2.62 \\
HAG2 & $\mathrm{y}=-2.0656 \mathrm{x}^{2}+9.4215 \mathrm{x}+38.696$ & 0.73 & 2.75 & $<0.0008$ & 2.28 \\
HAG3 & $\mathrm{y}=-1.5888 \mathrm{x}^{2}+6.7713 \mathrm{x}+37.863$ & 0.61 & 2.39 & $<0.0013$ & 2.03 \\
HAG4 & $\mathrm{y}=-3.7948 \mathrm{x}^{2}+22.203 \mathrm{x}+19.738$ & 0.82 & 1.52 & $<0.0001$ & 2.93 \\
HAG5 & $\mathrm{y}=-3.0556 \mathrm{x}^{2}+17.104 \mathrm{x}+23.599$ & 0.83 & 1.91 & $<0.0001$ & 2.79 \\
\hline
\end{tabular}

Forest topsoil HA from Guarany location promoted highest lateral root induction (Figure 2A), followed by HA isolated from eucalyptus (HAG2) and $y v y-h u$ (HG3) sites. For Guarany sites, the HA isolated from cultivated soils induced less pronounced effect over lateral root development. The HA from Q2 sandy soil, which were 
used for multicropping promoted greater induction of lateral root emergence. Considering the length of principal root (Figure 2B), the HA isolated from forest topsoil also allowed general root growth. The HAQ2 isolated from multicropping system reduced the length of principal root, while this was as effective for HAG2 $(y v y-h u)$ as for the reference sample (HAG1). Samples from multicropping and "tired" sites (HAG4 and HAG5, respectively) induced lowest humic bioactivity among all HA evaluated, since, both, lateral root emergence stimulation and principal root elongation were less effective.

\section{Discussion}

Soil organic matter influences ecosystem cycles of carbon, nitrogen and other major elements and traditionally serves as a major soil fertility parameter. SOM has been increasingly considered among the major indicators of soil quality, as much as one of the basic components of biosphere sustainability and stability (Slepetiene \& Slepetys, 2005). Despite their importance for agriculture and environmental protection, definitions about quantity and quality of SOM and of its major component, HS, remain as challenger in humic science. A number of studies are available about the influence of management practices, especially for fertilizing and soil tillage systems, on SOM quality (Piccolo, 1996). Traditional peasants usually consider SOM as important requisite for agriculture maintenance and their wisdom has been used by soil scientists as an indication for sustainable soil fertility and management practices (Altieri, 1993). Notwithstanding, analysis of chemical characteristics of SOM in sites under traditional peasants practices was scarcely studied, although it may be in line with scientific findings and useful to establish valuable parameters about SOM quality.

In this work we investigated what were the major factors that influence soil quality evaluation and decisions to apply specific practices of two traditional peasants communities. In order to avoid simplifications, a research couple lived for two months in the selected communities. Responses obtained by the communities were accompanied by collection of soils at sites indicated by peasants and their humic content was evaluated using several approaches (humus classical fractionation, 13C-CPMAS-NMR spectroscopy, elemental characteristics, size exclusion chromatography, and biological assays). We compared results with that of reference samples (collected on forest topsoil in each site) and with previously reported long-term experiment.

The two traditional communities under study were very different in several aspects: language, climate influence, cultural heritage. In the Quilombola place live African descendents that arrived to North of Rio de Janeiro State to work as slaves at sugarcane plantations during the colonial period (1651). They remained in the same area and live today near the sea as temporary workers (manual harvest at sugarcane period). They are adapted to typical subsistence agriculture (with no market interest) that is characterized by multicropping system on Oxisols. Guarany Indians live at Salto do Jacuí reserve and make part of a major Indian Nation that used to be spread until colombian contact (1532) through south of Brazil, Paraguay and Argentina. After this the Guarany were continuously reduced and their survivors were confined in restricted area. Modern agribusiness, especially cattle and soybean plantation limit their continuous migration and no cultural link with ancestors is observed today. However, some aspects are used as tools of cultural resistance, especially tillage and language. Guarany apply slash and burn tillage even today, use their own seeds and plants for propagation (mainly maize and cassava), and, despite the pressure from extension governmental agency to modernize Guarany agriculture, no modern tillage practices were introduce in the studied sites. Differently from Quilombola, soils in the Guarany reserve are rich in clay content and topography is rough. However, some religious and cultural aspects are utilized to select local multicropping system. In their sites, we collected soil samples at native forest topsoil (G1), under eucalyptus reforestation (G2), one soil indicated as very fertile due to presence of dark earth (yvy-hu or terra preta) (G3), and two soils described as less fertile (tired) for cultivation (G4 and G5).

Previous works demonstrated high correlation between soil local practices and conventional soil analysis (Sandor and Furbee, 1996; Gray and Morant, 2003). TOC content was larger in reference samples than in soils under peasant practices and decreased further with cultivation. This decrease was mainly due to reduction in carbohydrates content as revealed by ${ }^{13} \mathrm{C}$-CPMAS-NMR spectra and well related to previously reported humic dynamics in tropical areas (Zech et al., 1997; Spaccini et al., 2002; Piccolo et al., 2005; Spaccini et al., 2006). This change was followed by an increase in HA content in areas considered suitable for cultivation. Previous works (Zech et al., 1997; Piccolo et al., 2005; Spaccini et al., 2006) revealed that FA are composed mainly by polysaccharides and contain only small amounts of alkyl carbon and land use does not change carbons distribution. Conversely, HA are predominantly formed by hydrophobic carbon (aromatic- and alkyl-C) and this distribution varies considerably according to peculiar aspects of differences sites.

These assumption are in line with FA and HA definition proposed by Piccolo (2002) where FA are regarded as association of small hydrophilic molecules, whose acid functional groups are large enough to keep fulvic clusters 
dispersed in solution at any $\mathrm{pH}$, while $\mathrm{HA}$ are made by association of hydrophobic components (polymethylenic chains, fatty acids, steroids, terpenoids), which are stabilized at neutral $\mathrm{pH}$ by hydrophobic dispersive forces and flocculate at lower $\mathrm{pHs}$, when hydrogen bonds associate further the hydrophobic domains. A possible practical consequence is to indirectly evaluate the forces that maintain humic molecules in the status of aggregation.

In this work, the conformational behaviour of HA in solution was very distinct among the samples. In general, HA from forest topsoil was extracted in relatively greater amount and showed large molecular size components than for humic samples isolated from soils subjected to multicropping system. However, for the area considered fertile by Guarany (Table 1), the extracted HA was not only large, but had a size distribution very similar to that observed in reference samples, thereby suggesting that the Indian belief in the fertility of this soil was supported by scientific observations.

The hydrophobic humic components strongly affect the soil properties, being considered as main responsible for soil aggregation, SOC sequestration, and even stabilization of bioactive hydrophilic components (Spaccini et al., 2002; Dobbss et al., 2010; Song et al., 2013). In this direction, Canellas et al (2008a; 2009) found that HA with more hydrophobic moieties was more effective to promote root growth. In this work, lateral root emergence was stimulated by all HA. Canellas et al. (2010) in a long-term sugar-cane experiment on harvest management without burning, observed changes in SOM which induced accumulation of HA and concomitant increase of the hydrophobic character of stable organic matter. In addition, also the content of labile N, P and S compounds increased in soils in the treatment without burning, thus suggesting that the preservation of different labile compounds within humic hydrophobic domains limits their rapid microbial degradation.

The process of molecular trapping of small biolabile molecules into humic hydrophobic domains (Dobbss et al., 2010; Song et al., 2013) suggests that the larger the HA content, the greater was the potential protection of bioactive molecules, whereas the larger the chemical diversity of such bioactive molecules, the more diverse was their bioactivity. Moreover, Canellas et al. (2008b) showed that maize treated with HA enhanced exudation of organic acids in soil, being in line with the observed disruption of humic supramolecular associations by organic acids (Piccolo, 2002). The entrapped biomolecules may then be released and access cell membranes to induce different physiological responses.

The $\mathrm{C}$ species distribution by 13C-CPMAS-NMR was quite similar in samples, probably due close proximity among samples and little cultivation time (six years). However, the HA content, their size distribution and biological effects were sensitive parameters to detect differences among sampled sites. In conclusion, these results highlight that traditional agricultural practices lead to a relative increase of the hydrophobicity of humus. This appears a key mechanism to enhance labile forms of macronutrients and concomitantly decrease their rapid microbial degradation, thereby generating conservative management for nutrient re-cycling processes, and contributing to sustainable soil fertility (Canellas et al., 2008; 2009).

The local field sites matching the traditional cropping requirements, were characterized by larger soil chemical fertility and soil organic matter hydrophobicity, as compared to the land plots considered as inadequate by rural peasants. The HA from cropped soils revealed significant differences in respect to content, hydrophobicity, biostimulation and molecular dimension.

\section{Acknowledgements}

We wish to express sincere gratitude to Tania Treviso from EMATER-RS, Salto do Jacuí for all assistance on the Guarany reserve. We also wish to thank prof. Bartolomeu Meliá from Catholic University of Assunción, Paraguay, for inspiration and contribution related to the Guarany local knowledge history). Also we would like to deeply thanks the peasants comunity that give the opportunity to share with us their knowledge. $\mathrm{CNPq}$ and FAPERJ support this research.

\section{References}

Aguiar, N. O., Novotny, E. H., Oliveira, A. L., Rumjanek, V. M., Olivares, F. L., \& Canellas, L. P. (2013). Prediction of humic acids bioactivity using spectroscopy and multivariate analysis. Journal of Geochemical Exploratio, 129, 95-102. http://dx.doi.org/10.1016/j.gexplo.2012.10.005

Altieri, M. A. (1993). Ethnoscience and biodiversity: key elements in the design of sustainable pest management systems for small farmers in developing countries. Agriculture Ecosystem and Environment, 46, 257-272. http://dx.doi.org/10.1016/0167-8809(93)90029-O

Altieri, M. A. (2002). Agroecology: the science of natural resource management for poor farmers in marginal $\begin{array}{lllll}\text { environments. Agriculture Ecosystem and } & \text { Environment, } & 93, & 1-24 .\end{array}$ http://dx.doi.org/10.1016/S0167-8809(02)00085-3 
Barrios, E., Delve, R. J., \& Bekunda, M. (2006). Indicators of soil quality: A South-South development of methodological guide for linking local and technical knowledge. Geoderma, 135, 248-59. http://dx.doi.org/10.1016/j.geoderma.2005.12.007

Canellas, L. P., Zandonadi, D. B., Busato, J. G., Baldotto, M. A., Simões, M. L., Martin-Neto, L., ... Piccolo, A. (2008a). Bioactivity and chemical characteristics of humic acids from tropical soils sequence. Soil Science, 173, 624-637. http://dx.doi.org/10.1097/SS.0b013e3181847ebf

Canellas, L. P, Teixeira Junior, L. R. L., Dobbss, L. B., Silva, C. A., Medici, L. O., Zandonadi, D. B., \& Façanha, A. R. (2008b). Humic acids crossinteractions with root and organic acids. Annals of Applied Biology, 153, 157-166.

Canellas, L. P., Dobbss, L. B., Santos, G. A., Olivares, F. L., Spaccini, R., \& Piccolo, A. (2009). Relationships Between Chemical Characteristics and Root Growth Promotion of Humic Acids Isolated From Brazilian Oxisols. Soil Science, 174, 611-620. http://dx.doi.org/10.1097/SS.0b013e3181bf1e03

Canellas, L. P., Busato, J. G., Dobbss, L. B., Baldotto, M. A., Rumjanek, V. M., \& Olivares, F. L. (2010). Soil organic matter and nutrient pools under long-term non-burning management of sugar cane. European Journal of Soil Science, 61, 375-383. http://dx.doi.org/10.1111/j.1365-2389.2010.01229.x

Canellas, L. P., Dobbss, L. O., Oliveira, A. L., Chagas, J., Aguiar, N. O., Rumjanek, V., ... Piccolo, A. (2012). Chemical properties of humic matter as related to induction of plant lateral roots. European Journal of Soil Science, 63, 315-324. http://dx.doi.org/10.1111/j.1365-2389.2012.01439.x

Dobbss, L. B., Canellas, L. P., Olivares, F. L., Aguiar, N. O., Peres, L. E. P., Azevedo, M., ... Facanha, A. R. (2010). Bioactivity of Chemically Transformed Humic Matter from Vermicompost on Plant Root Growth Journal of Agricultural and Food Chemistry, 58, 3681-3688.

Diacomo, M., \& Montemurro, F. (2010). Long-term effects of organic amendments on soil fertility. A review. Agronomy Sustainable Development, 30, 401-422. http://dx.doi.org/10.1051/agro/2009040

Gray, L. C., \& Moran, P. (2003). Reconciling indigenous knowledge with scientific assessment of soil fertility changes in south-western Burkina Faso. Geoderma, 111, 425-437. http://dx.doi.org/10.1016/S0016-7061(02)00275-6

Herrick, J. E., \& Wander, M. M. (1998). Relationships between soil organic carbon and soil quality in cropped and rangeland soils: The importance of distribution, composition, and soil biological activity. In R. Lal, J. M. Kimble, R. F. Follet \& B. A. Stewart (Eds.), Soil processes and the carbon cycle (pp. 405-425). Boca Raton, CRC Press.

Kelleher, B. P., \& Simpson, A. J. (2006). Humic substances in soils: are they really chemically distinct? Environmental Science and Technology, 40, 4605-4611. http://dx.doi.org/10.1021/es0608085

Kononova, M. M. (1961). Soil organic matter: Its nature, its role in soil formation and in soil fertility. (p. 54) New York: Pergamon Press.

Lefèvre, V., Capitaine, M., Peigné, J., \& Roger-Estrade, J. (2013). Farmers and agronomists design new biological agricultural practices for organic cropping systems in France. Agronomy Sustainable Development.

Nardi, S., Morari, F., Berti, A., Tosoni, M., \& Giardini, L. (2004). Soil organic matter properties after 40 years of different use of organic and mineral fertilisers. European Journal of Agrononomy, 21, 357-367. http://dx.doi.org/10.1016/j.eja.2003.10.006

Orlov, D. S. (1985). Humic acids of soils. United States Dept. of Agriculture (USDA) and the National Science Foundation (NSF) (p. 378), Washington DC, by Amerind Pub, Washington.

Piccolo, A. (1996). Humus and soil conservation. In: Humic Substances in Terrestrial Ecosystems. Piccolo A (ed.). Elsevier, Amsterdam, The Netherlands. http://dx.doi.org/10.1016/B978-044481516-3/50006-2

Piccolo, A. (2001). The supramolecular structure of humic substances. Soil Science, 166, 810-832. http://dx.doi.org/10.1097/00010694-200111000-00007

Piccolo, A. (2002). The supramolecular structure of humic substances. A novel understanding of humus chemistry and implications in soil science. Advances in Agronomy, 75, 57-134. http://dx.doi.org/10.1016/S0065-2113(02)75003-7

Piccolo, A., Conte, P., Spaccini, R., \& Mbagwu, J. S. C. (2005). Influence of land use on the humic substances of 
some tropical soils of Nigeria. Europena Journal of Soil Science, 56, 343-352. http://dx.doi.org/10.1111/j.1365-2389.2004.00671.x

Saidou, A., Kuyper, T. W., Kossou1, O. K., Tossou1, R., \& Richards, P. (2004). Sustainable soil fertility management in Benin: learning from farmers. NJAS Wageningen Journal of Life Science, 52, 349-369. http://dx.doi.org/10.1016/S1573-5214(04)80021-6

Sandor, J. A., \& Furbee, L. (1996). Indigenous knowledge and classification of soils in the Andes of Southern Peru. Soil Science Society America Journal, 60, 1502-1512. http://dx.doi.org/10.2136/sssaj1996.03615995006000050031x

Slepetiene, A., \& Slepetys, J. (2005). Status of humus in soil under various long-term tillage systems. Geoderma 127, 207-215. http://dx.doi.org/10.1016/j.geoderma.2004.12.001

Soil Survey Staff. (2010). Keys to soil taxonomy. United States Department of Agriculture, eleventh ed. Natural Resources Conservation Service, Washington, DC.

Song, X. Y., Spaccini, R., Pan, G., \& Piccolo, A. (2013). Stabilization by hydrophobic protection as a molecular mechanism for organic carbon sequestration in maize-amended rice paddy soils. The Science of The Total Environment, 458-460, 319-330. http://dx.doi.org/10.1016/j.scitotenv.2013.04.052

Spaccini, R., Piccolo, A., Mbagwu, J. S. C., Teshale, A. Z., \& Igwe, C. A. (2002). Influence of the addition of organic residues on carbohydrate content and structural stability of some highland soils in Ethiopia. Soil Use and Management, 18, 404-411. http://dx.doi.org/10.1111/j.1475-2743.2002.tb00259.x

Spaccini, R., Piccolo, A., Conte, P., \& Mbagwu, J. S. C. (2006). Changes of humic substances characteristics from forested to cultivated soils in Ethiopia. Geoderma, 132, 9-19. http://dx.doi.org/10.1016/j.geoderma.2005.04.015

Stevenson, F. J. (1994). Humus chemistry: Genesis, Composition, Reactions (2nd ed.) New York: Wiley.

Striegel, A. M., Yau, W. W., Kirkland, J. J., \& Bly, D. D. (2009). Modern size-exclusion liquid chromatography Practice of Gel Permeation and Gel Filtration Chromatography. New Jersey: A John Wiley \& Sons, Inc.

Vaughan, D., \& Malcolm, R. E. (1985). Soil organic matter and biological activity. Kluwer, Dordrecht. http://dx.doi.org/10.1007/978-94-009-5105-1

Zandonadi, D. B., Canellas, L. P., \& Façanha, A. R, (2007). Indolacetic and humic acids induce lateral root development through a concerted plasmalemma and tonoplast $\mathrm{H}+$ pumps activation. Planta, 225, 1583-1595. http://dx.doi.org/10.1007/s00425-006-0454-2

Zech, W., Senesi, N., Guggenberger, G., Kaiser, K., Lehmann, J., Miano, T. M., ... Schrolth, G. (1997). Factors controlling humification and mineralization of soil organic matter in the tropics. Geoderma, 79, 117-161. http://dx.doi.org/10.1016/S0016-7061(97)00040-2

\section{Copyrights}

Copyright for this article is retained by the author(s), with first publication rights granted to the journal.

This is an open-access article distributed under the terms and conditions of the Creative Commons Attribution license (http://creativecommons.org/licenses/by/3.0/). 